\title{
Feeding Group Zonation of Ephemeroptera (Insecta) at Plalar-Gremeng River, Gunung Sewu Karst Ecosystem, Gunungkidul, Yogyakarta Special Province, Indonesia
}

\author{
Suwarno Hadisusanto and Ari Kristanto \\ Laboratory of Ecology and Conservation, Faculty of Biology, Universitas Gadjah Mada, Yogyakarta 55281, Indonesia
}

\begin{abstract}
The objectives of this research were to record the changes in composition of the community of ephemeroptera in Plalar-Gremeng river, examine the causes of these changes and discover their significance in the life of the rivers. The ephemeropteran community and abundance of the feeding group (detritivore, gatherer and scrapper) were compared with the nutrient and water quality of each sampling site. It is established that, under site conditions, nutrient status can be regarded as the chief internal factors. The method was field survey for sampling the substrate at five sites: (1) Up-stream of Plalar river; (2) The site before the Plalar cave; (3) The total dark zone of Plalar-Gremeng caves; (4) The site after Gremeng cave and (5) The down-stream of Gremeng to Beton river. Substrate sampling used Surber benthic sampler and the sample was containing and labeling. Environmental parameters were measured water temperature, carbon dioxide, velocity, $\mathrm{pH}$, C-organic, sediment total-phosphorus and nitrogen and $\mathrm{Ca}$ content. The data was analyzed by description. The results showed that the abundance of ephemeroptera was highest at site-4 and the lowest at site-3. Ephemeropthera play a highly important role in preserving nutrient status.
\end{abstract}

Key words: Feeding group, ephemeroptera, Plalar-Gremeng river, karst ecosystem, Gunungkidul.

\section{Introduction}

The task of this research which was carried out between October-December 2005 was to study the qualitative and quantitative composition of the sediment-dwelling genera of ephemeropteran fauna in Plalar-Gremeng river. Factually, based on longitudinal axis, both Plalar and Gremeng were river. But up-stream and down-stream bordered by the cave in a small hill. These presentation for the evaluation and separation of the feeding group as a spatial separation moving. The change was occurring in the nutrient and water quality. A review of literature on the sediment dwelling organisms especially ephemerop- terans have already been given [1].

This paper aims at providing a summarizing evaluation of previous results. One of the trophic level is detritivore (insect larvae, worms and crustaceans).

Corresponding author: Suwarno Hadisusanto, Ph.D., limnologist, research field: benthonic.
The detritivore is the organisms which digest and recycle a portion back into the overlaying waters [2]. The life-cycle of three species-Baetis alpinus, Baetis melanonyx and Rhitrogena iridina are at Wolosatka and Tereboviec streams, Bieszczady national park, southeastern Poland [3]. Baetis alpinus took various courses depending on environment condition. Baetis alpinus has $1 \%-4.9 \%$ average percentage contribution [4].

\section{Material and Methods}

The ephemeroptera larvae were collected from Plalar and Gremeng rivers at Gunung Sewu karst ecosystem, Ponjong, Gunungkidul, Yogyakarta special province. The sampling location lies in the eastern part of the Gunung Sewu geological formation and is underline by limestone area. Sampling site of the river $\left(110^{\circ} 45^{\prime} 30^{\prime \prime} \mathrm{E}\right.$ and $\left.7^{\circ} 58^{\prime} 30^{\prime \prime} \mathrm{S}\right)$ is about 16.5 $\mathrm{km}$ from Wonosari (center of the local Gunungkidul government). 

Ecosystem, Gunungkidul, Yogyakarta Special Province, Indonesia

Attention was mainly focused on describing differences along the longi-tudinal axis of the Plalar-Gremeng river. The sampling design was stratified purposive random sampling [1].

The river in this area was surveyed and could be devided into five section with the characteristic condition. The five sites for sampling location based on the water current or longitudinal fiew, from up-stream to down-stream of the river here:

Site-1: The up-stream of Plalar river;

Site-2: The site before the Plalar cave;

Site-3: The total dark zone of Plalar-

Gremeng caves;

Site-4: The site after Gremeng cave;

Site-5: The down-stream of Gremeng to

Beton river.

The benthic macro-invertebrate fauna was collected by a Surber sampler which sampled an area of $25 \mathrm{~cm}$ $\times 25 \mathrm{~cm}$ to $3 \mathrm{~cm}$ depth [5]. The net bag had a mesh size of $250 \mu \mathrm{m}$, the sample was containing and labeling. Weekly sampling was carried out on typical riffle on the river. The total content of the Surber-net was washed into a sample container. The sample were isolated and preserved in $2 \%$ formal-dehyde [6]. In the laboratory, the ephemeropteran were separated from another organisms. Finally, the sample was identified in binocular and supported the check-list.

Environmental parameters were measured water temperature, carbon dioxide, water velocity, $\mathrm{pH}$, C-organic; total-nitrogen and phosphorus substrate and $\mathrm{Ca}$ content. The data was analyzed by description.

\section{Results and Discussion}

The Table 1 showed community of ephemeropteran in the Gremeng river - the one of river in karst ecosystems, Gunungkidul, Yogyakarta special province, Indonesia. There were three main feeding behavior organisms of order ephemeroptera. The three feedding behavior are detritivore, gatherer and scrapper. But there is an organism as detritivore, gatherer and scrapper in functional, which is Caenis Centroptilum, Baetis and Leptohyphes - all of them as detritivore in trophic level. Getherer organisms at the sampling site just three genera. There are two identified genera: Atalophlebia and Siplonurus, and one un-identified genus is called genus A. The scrapper there was just one genus only-Heptagenia.

The abundance of ephemeropteran members recorded in Table 2 shows that the feeding group benthic fauna is dominated by gatherer 455 individuals, detritivore 270 individuals and scrapper 14 individuals only. The multiple feeding type was found in Caenidae (as detrivore, gatherer and scrapper), there was only 6 individuals. The results showed the abundance of ephemeroptera highest at site-4 (Gremeng river) and the lowest at site-3 (in the dark zone of the cave).

Fig. 1 shows the abundance of ephemeropterans at sampling site: site-2, very abundant; site-4, abundant; site- 5 and site- 1 , common $(150<\mathrm{x}<200$ individuals $)$. The abundance was very rare in site- 3 because ephemeropteran can not adapt to the inside cave. The gatherer organisms was more abundance than another

Table 1 Members of ephemeroptera in research survey.

\begin{tabular}{lll}
\hline Feeding group & Family & Genera \\
\hline Detritivore & Baetidae & Centroptilum \\
& & Baetis \\
Gatherer & Tricorythidae & Leptohyphes \\
& Leptophlebiidae & Atalophlebia \\
& & Genus A \\
Scrapper & Siplonuridae & Siplonurus \\
Detritivore, Gatherer and Scrapper & Heptagenidae & Heptagenia \\
\hline
\end{tabular}


Feeding Group Zonation of Ephemeroptera (Insecta) at Plalar-Gremeng River, Gunung Sewu Karst Ecosystem, Gunungkidul, Yogyakarta Special Province, Indonesia

Table 2 Individual number of genera at Plalar-Gremeng river.

\begin{tabular}{|c|c|c|c|c|c|c|c|}
\hline \multirow{2}{*}{ Feeding group } & \multirow{2}{*}{ Family } & \multirow{2}{*}{ Genera } & \multicolumn{5}{|c|}{ Number of individuals at sampling site } \\
\hline & & & 1 & 2 & 3 & 4 & 5 \\
\hline \multirow[t]{2}{*}{ Detritivore } & Baetidae & Centroptilum & 28 & 1 & 0 & 91 & 0 \\
\hline & & Baetis & 0 & 20 & 0 & 72 & 7 \\
\hline \multirow[t]{4}{*}{ Gatherer } & Tricorythidae & Leptohyphes & 2 & 36 & 4 & 9 & 0 \\
\hline & Leptophlebiidae & Atalophlebia & 1 & 26 & 3 & 1 & 175 \\
\hline & & Genus A & 141 & 41 & 0 & 15 & 6 \\
\hline & Siplonuridae & Siplonurus & 5 & 29 & 0 & 12 & 0 \\
\hline Scrapper & Heptagenidae & Heptagenia & 6 & 0 & 0 & 5 & 3 \\
\hline $\begin{array}{l}\text { Detritivore, Gatherer } \\
\text { and Scrapper }\end{array}$ & Caenidae & Caenis & 1 & 5 & 0 & 0 & 0 \\
\hline Total & & & 184 & 158 & 7 & 205 & 191 \\
\hline
\end{tabular}

organisms (detritivore and scrapper) because there was many litter from vegetations. Detritivore organisms were less than gatherer but were not indicator for an limestone aquatic ecosystem. The same discussion for scrapper organisms was very rare there, maybe nutrition as limited factors.

Fig. 2 showed abundance of ephemeropteran combination of sampling site and feeding group. Gatherer was abundant at site-1, site-2 and site-5, and detritivore organisms was abundant at two sites-site-2 and site-4. There was negative correlation between abundance of gatherer and detritivore organisms. While, epheme-ropteran abundance is very rare inside the cave.

In Fig. 2, detritivores was dominant at site-4. There were 172 individuals especially genera Centroptilum and Baetis, while Leptohypes dominant at site-2. Centroptilum and Baetis had the same family-Baetidae, so similar in the sub-habitat. Another group gatherer was dominate at site-5, there was 181 individuals. The site- 5 is the site in Gremeng river nearby the main stream Beton river, so many nutrients are from the up-stream of the watershed. Beside that, the scrapper organism is only one genus Heptagenia, it's low abundant, the total individuals which is highest has only six individuals. In general, dominancy depend on sampling sites for example site-4 is highest: 205 individuals; site-5: 191 individuals; site-1: 184; site-2: 158 and the rarely site-3: 7 individuals only.

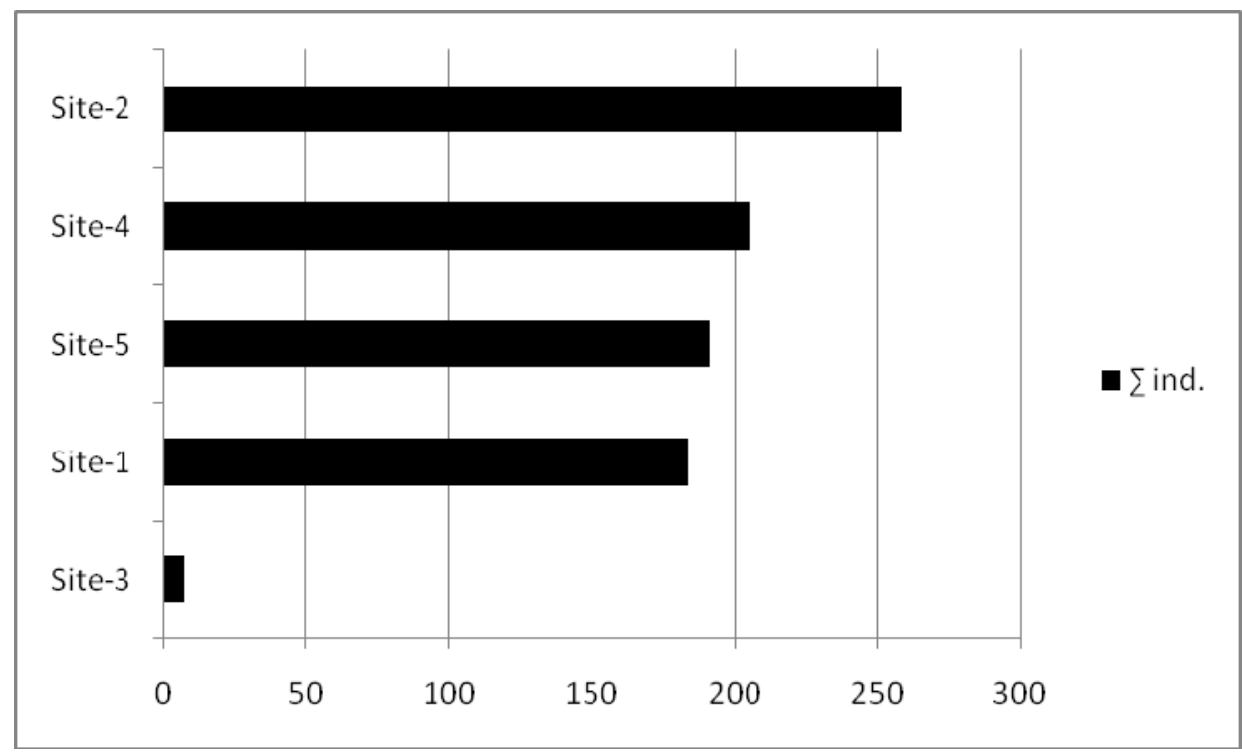

Fig. 1 Individuals ratio between sampling site at Plalar-Gremeng river. 

Ecosystem, Gunungkidul, Yogyakarta Special Province, Indonesia

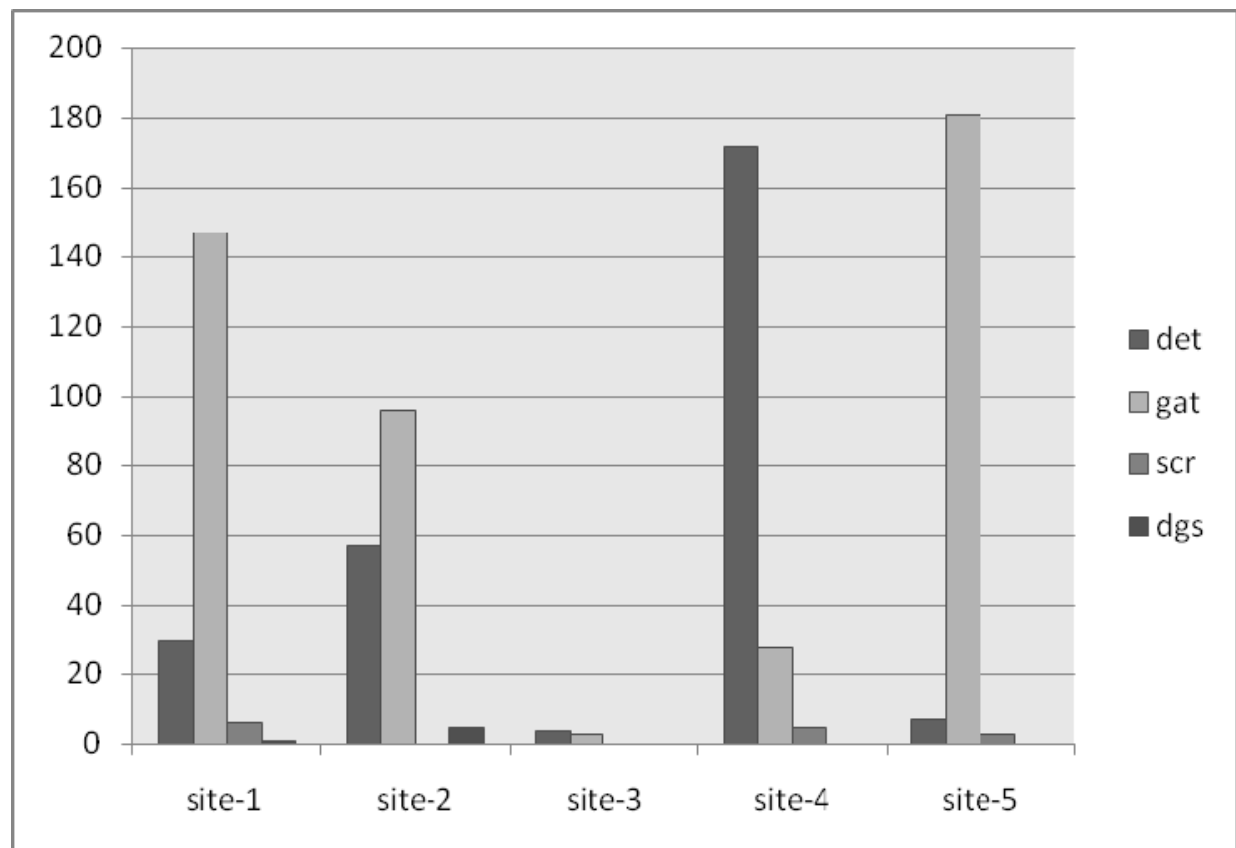

Fig. 2 Abundance of the feeding group of ephemeroptera at five sampling site (site-1: the up-stream, site-2: before the Plalar cave, site-3: in the cave, site-4: after Gremeng cave and site-5: down-stream) det-detritivor, gat-gatherer, scr-scrapper and dgs-detritivor-gatherer-scrapper.

The organisms which more than one type of feeding habits is very rare in this research. This case was supposed that there is correlation with substrate or ecosystem type because the water body in limestone condition.

Percentage of abundance based on sampling site is shown in Fig. 3. The biggest percentage of ephemeropteran is at site- $4: 27.52 \%$, and higher than site-5: $25.64 \%$, site- $1: 24.70 \%$ and site-2: $21.21 \%$, and smallest at site-3: $0.94 \%$. Both the site- 1 and the site-4 are relatively the same in percent maybe because the same on micro-habitat condition (open water so radiation through to the substrate).

Fig. 4-the percentage of abundance based on feeding group showed that the biggest percentage of ephemeropteran is gatherer: $55.04 \%$, higher than detritivore: $41.86 \%$, scrapper: $2.17 \%$ and the smallest: $0.93 \%$. Water temperature is limiting factor for organisms existence. The water temperature is a major factor determining egg development and nymphal growth [3]. Caenis (Caenidae) was supposed its very sensitive to the temperature condition because all of site are very shallow becoming rare in abundance.

The data of the water-substrates quality were shown in Table 3. The carbon dioxide at site- 3 and site- 5 was higher than another site because of inside the cave and high in abundance of ephemeropteran. Karst was developed by limestone, whose $\mathrm{pH}$ was between 8.39-8.70. Ca contents was going-down from up-stream to down-stream (site-1 to site-5), which was supposed that limestone was errodibility more little at down-stream. Ephemeroptera belonging to environmentally sensitive aquatic insects [7].

The influence of nutrient ( $\mathrm{N}$ and $\mathrm{P}$ contents) is not clear among the five sampling sites. Gradation in substrate makes difference in environmental parameters and finally in communty of the benthic organisms. These cases were similar with the characteristic gradient of the sediment quality in the Sempor dam which showed different benthic community [8]. 

Ecosystem, Gunungkidul, Yogyakarta Special Province, Indonesia

Fig. 3 Percentage of ephemeropteran based on sampling site: site-1: up-stream (24.70\%), site-2: before the cave (21.21\%), site-3: inside ( $0.94 \%)$, site-4: after the cave $(27.52 \%)$ and site-5: down-stream $(25.64 \%)$.

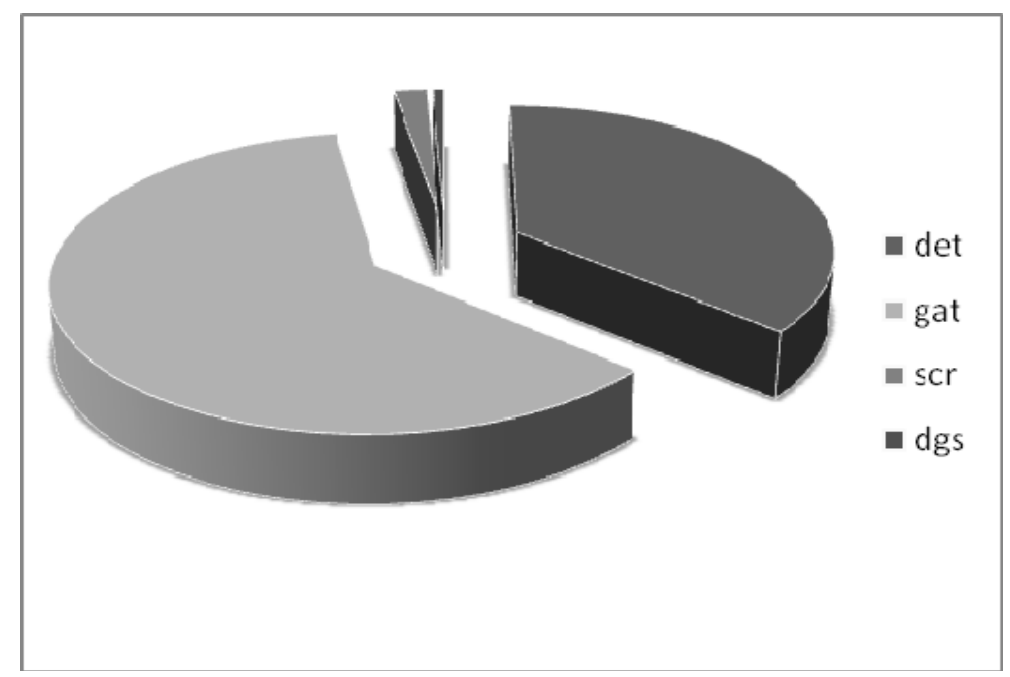

Fig. 4 Percentage of ephemeroptera based on feeding group: det-detritivore (41.86\%), gat-gatherer (55.04\%), scr-scrapper $(2.17 \%)$ and dgs-all of type $(0.93 \%)$.

Table 3 The water-substrates quality and the abundance of ephemeropteran.

\begin{tabular}{lrrrrr}
\hline Parameters/sites & \multicolumn{1}{c}{2} & \multicolumn{2}{c}{3} & \multicolumn{2}{c}{4} \\
\hline Water temperature $\left({ }^{\circ} \mathrm{C}\right)$ & 25.50 & 25.44 & 25.00 & 25.60 & 28.65 \\
$\mathrm{CO}_{2}(\mathrm{ppm})$ & 5.13 & 5.63 & 7.98 & 4.83 & 9.28 \\
Velocity (cm/s) & 30.09 & 11.22 & 6.20 & 40.09 & 5.55 \\
$\mathrm{pH}$ & 8.46 & 8.56 & 8.55 & 8.70 & 8.39 \\
C-org (\%) & 0.55 & 0.73 & 0.18 & 0.18 & 0.18 \\
Nitrogen-substrate (ppm) & 0.011 & 0.01 & 0.007 & 0.008 & 0.004 \\
Phosphorus-substrate (ppm) & 20.23 & 10.30 & 12.14 & 4.71 & 12.12 \\
Ca (\%) & 3.75 & 2.91 & 1.40 & 1.94 & 1.64 \\
Ephemeropteran (total ind.) & 184 & 158 & 7 & 205 & 191 \\
\hline
\end{tabular}




\section{Conclussions}

According to the results, there are conclusions:

(1) There were six families and eight genera;

(2) There was community converted (distribution, abundance and composition) of the ephemerop-teran in each site;

(3) The trophic feeding group was dominated by gatherer type: Atalophlebia, genus A and Siplonurus;

(4) The highest abundance was at the site-4 - the sampling location between Gremeng cave and main stream Beton river;

(5) There is one genus as multiple feeding behavior (detritivore, getherer and scapper), Caenis.

\section{Acknowledgements}

The author should like to thank the students who assist the research Ari and Ifa.

\section{References}

[1] Devai, G. 1990. "Ecological Back-Ground and Importance of the Change of Chironomid Fauna (Diptera: Chironomidae) in Shallow Lake Balaton.” Hydrobiologia
191: 189-198.

[2] Horne, A. J., and Goldman, C. R. 1994. Limnology, International Student Edition. New Delhi: McGraw-Hill International Book Company.

[3] Kukula, K. 1997. "The Life Cycles of Three Species of Ephemeroptera in Two Stream in Poland." Hydrobiologia 353: 193-198.

[4] Jackson, P. D. 1978. "Benthic Invertebrate Fauna and Feeding Relationship of Brown Trout, Salmo trutta Linaeus and River Blackfish, Gadopsis marmoratus Richardson in the Aberfeldy River, Victoria." J. M. Freshwater Res. 29: 715-724.

[5] Brower, J. E., Zar, J. A., and Ende, C. N. 1998. Field and Laboratory Methods for General Ecology, Fourth Edition. Boston: W.C.B. McGraw-Hill.

[6] Wetzel, R. G., and Likens, G. E. 1991. Limnological Analyses, Second Edition. Philadelphia: Saunders College Publishing.

[7] DeWalt, R. E., and South, E. J. 2015. "Ephemeroptera, Plecoptera and Trichoptera on Isle Royal National Park, U.S.A., Compared to Mainland Species Pool and Size Distribution." Zookeys 532: 137-158.

[8] Hadisusanto, S. 2008. "Distribution and Abundance of Chironomidae (Diptera) Benthonic Larvae: It's Relation with Depth and Nutrient in Sempor Reservoir, Central Java, Indonesia." Presented at The 4th Life Sciences Postgraduate Conference. 